\title{
IDENTIFIKASI PRIORITAS SEKTOR-SEKTOR POTENSIAL GUNA MERANCANG STRATEGI PENGEMBANGAN PEMBANGUNAN MELALUI ANALISIS SHIFT-SHARE DAN SWOT
}

\author{
Sarmadi dan Eko Budi Leksono \\ Jurusan Teknik Industri \\ Universitas Muhammadiyah Gresik \\ Email : eko_budileksono@umg.ac.id
}

\begin{abstract}
ABSTRAK
$\mathrm{D}$ alam rangka merumuskan perencanaan pembangunan pemerintah daerah yang baik, maka dibutuhkan suatu strategi pengembangan terhadap sektor-sektor potensial daerah yang dapat berfungsi sebagai pedoman dan arah pelaksanaan pembangunan guna meningkatkan perekonomiannya. Pada beberapa kasus, suatu daerah kurang jeli dalam mengidentifikasi sektor-sektor potensial sehingga banyak dijumpai suatu pengembangan dan atau pembangunan yang dilakukan suatu daerah tidak tepat sasaran, sehingga perlu adanya suatu penelitian yang dapat mengidentifikasi prioritas pengembangan sektor-sektor potensial sehingga pembangunan daerah sesuai pada sasaran serta rancangan strategi pengembangan terhadap sektor-sektor tersebut.

Dalam mengidentifikasi sektor-sektor potensial digunakan analisis shift share untuk menghitung perubahan pertumbuhan (pergeseran) sektor-sektor potensial guna menghasilkan prioritas. Sedangkan untuk merancang strategi pengembangan menggunakan teknik SWOT.

Dari hasil analisis shift share terhadap daerah Gresik, beberapa sektor potensial yang layak dikembangkan adalah sektor industri pengolahan, sektor perdagangan, hotel dan restoran dan sektor pertanian.
\end{abstract}

Kata kunci: Pengembangan sektor Potensial; Analisis Shift-Share, SWOT

\section{PENDAHULUAN}

Dalam rangka merumuskan perencanaan pembangunan pemerintah kabupaten/kota yang baik, maka dibutuhkan suatu strategi pengembangan terhadap sektor-sektor potensial di suatu daerah yang dapat berfungsi sebagai pedoman dan arah pelaksanaan pembangunan guna meningkatkan perekonomiannya. Pada beberapa kasus, suatu daerah kurang mengidentifikasi prioritas pengembangan sektor-sektor potensial sehingga banyak dijumpai suatu pengembangan dan atau pembangunan yang dilakukan suatu daerah kurang tepat sasaran.

Untuk mengidentifikasi sektor-sektor potensial yang dapat dikembangkan dalam rangka pembangunan daerah, maka diperlukan analisis terhadap produk domestik regional bruto (PDRB) dengan cara membandingkan PDRB suatu daerah dengan PDRB provinsi. Sebagai contoh dalam makalah ini, unggulan Gresik di bidang industri membuat sektor itu setiap tahun menjadi penyumbang terbesar bagi PDRB. Pada PDRB Gresik tahun 2005, misalnya, industri pengolahan 100 menempati posisi pertama dengan 47,2\% dari total PDRB. Untuk PDRB per kapita tahun 2005, besarnya mencapai Rp 8,1 juta dan menempati peringkat ketiga terbesar di Provinsi Jawa Timur, setelah Kota Kediri dan Kota Surabaya.

Kabupaten Gresik termasuk wilayah yang tanahnya kurang subur untuk bercocok tanam, karena sebagian besar terletak di dataran rendah. Oleh karena itu, Gresik tidak terlalu mengandalkan sektor pertanian sebagai unggulannya. Untuk sektor pariwisata, khususnya wisata alam, tidak terlalu banyak lokasi wisata yang dimiliki Gresik.

Dari uraian diatas maka perlu kiranya Kabupaten Gresik mengidentifikasi secara strategis sektorsektor potensial guna menunjang PDRBnya agar tidak terlalu tergantung pada industri pengolahan saja.

\section{Perumusan Masalah}

1. Bagaimana mengidentifikasi sektor-sektor potensial secara strategis, khususnya di Kabupaten Gresik?

2. Bagaimanakah strategi pengembangan dalam rangka meningkatkan ekonomi daerah melalui 
sektor-sektor potensial?

\section{Tujuan Penelitian}

1. Mengidentifikasi sektor-sektor potensial di Kabupaten Gresik.

2. Merancang strategi pengembangan dalam rangka meningkatkan perekonomian daerah melalui sektor-sektor potensial.

\section{Tinjauan Pustaka}

\section{Perencanaan Pembangunan Ekonomi}

Pada tahap-tahap awal pembangunan menurut Bintoro Cokroamidjojo perencanaan pada umumnya berkenaan dengan bidang ekonomi, oleh karena itu kecenderungan utama adalah bahwa ilmu perencanaan yang berkembang paling maju adalah perencanaan ekonomi (Tjokroamidjojo. 1996).

Dari sudut pandang ekonomi alasan perlunya perencanaan ekonomi adalah agar : (1) alokasi sumberdaya-sumberdaya pembangunan yang terbatas bisa, efisien dan efektif sehingga dapat dihindari adanya pemborosan-pemborosan, (2) perkembangan ekonomi atau pertumbuhan ekonomi mantap dan berkesinambungan. (3) stabilitas ekonomi tercapai dalam menghadapi siklus konjungtur (Arsyad. 1999).

\section{Pertumbuhan Ekonomi}

Salah satu tujuan perencanaan ekonomi bagi negara-negara berkembang adalah untuk meningkatkan laju pertumbuhan ekonomi. Untuk meningkatkan pertumbuhan tersebut berarti perlu meningkatkan laju pembentukan modal dengan cara meningkatkan tingkat pendapatan, tabungan dan investasi. Tetapi peningkatan laju pembentukan modal ini menghadapi berbagai kesulitan, diantaranya kemiskinan masyarakat itu sendiri. Akibatnya laju investasi rendah dan berpengaruh pada rendahnya modal dan produktivitas. Keadaan inilah yang sering disebut lingkaran setan kemiskinan (vicious circle of poverty). Untuk memotong lingkaran setan diperlukan suatu pembangunan yang terencana (Arsyad, 1999).

\section{Keseimbangan Pertumbuhan}

Dalam suatu negara atau daerah yang sedang berkembang selalu menghadapi masalah pertumbuhan ekonomi yang lamban, tingkat pendapatan per kapita yang rendah serta belum berkembangnya sektor-sektor ekonomi. Untuk meningkatkan laju pertumbuhan ekonomi dan meningkatkan pendapatan per kapita perlu dipacu kemampuan produksi dari sektor-sektor ekonomi. Caranya dengan melakukan investasi sebesar mungkin dalam sektor-sektor tersebut agar dapat meningkatkan produktivitasnya.

Upaya meningkatkan laju pertumbuhan ekonomi dan pendapatan per kapita tersebut ada dua strategi, yaitu strategi pembangunan seimbang dan strategi pembangunan tak seimbang.

\section{Strategi Pembangunan Seimbang}

Strategi pembangunan seimbang bisa diartikan sebagai pembangunan berbagai jenis industri secara bebarengan (simultaneous) sehingga industri tersebut saling menciptakan pasar bagi yang lain. Selain itu strategi pembangunan seimbang ini dapat diartikan pula sebagai keseimbangan pembangunan di berbagai sektor. (Arsyad, 1999).

Semua sektor ekonomi harus digerakkan bersama agar diperoleh hasil yang optimal. Karena tidak ada satu sektorpun yang tidak berkaitan dengan sektor yang lain. Hal ini menimbulkan konsekuensi bahwa negara atau daerah yang bersangkutan harus menyediakan dana pembangunan untuk investasi yang sangat besar. Di daerah yang sedang berkembang selalu tejadi kecenderungan larinya dana pembangunan untuk diinvestasikan ke daerahdaerah yang relatif lebih maju yang infrastruktumya lebih lengkap.(Sukamto, 1990).

\section{Strategi Pembangunan Tak Seimbang}

Menurut Lincoln Arsyad yang disarikan dari pendapat Albert O. Hirschman dan Poul Streeten bahwa : "Menurut mereka, pembangunan tidak seimbang adalah pola pembangunan yang lebih cocok untuk mempercepat proses pembangunan di Negara Sedang Berkembang (NSB). Selanjutnya Hirschman berpendapat bahwa pembangunan sektor pemimpin (leading sector) akan merangsang sektor lainnya." (Arsyad, 1999).

Dalam teori pembangunan tak seimbang, strategi pembangunan seimbang dianggap tidak realistis karena sangat besar dana yang dibutuhkan. Sedangkan dana merupakan barang langka bagi daerah yang sedang berkembang. Bila dana pembangunan yang kecil harus dibagibagi ke semua sektor, maka akan terlalu kecil untuk dapat menggerakkan sektor-sektor usaha sehingga hasilnya akan sia-sia. Jadi lebih baik dana pembangunan yang jumlahnya terbatas tersebut dikonsentrasikan pada sektor-sektor pemimpin dan sektor potensial yang mampu memicu dan menggerakkan sektor-sektor yang lain untuk berproduksi, meningkatkan produksi dan meningkatkan produktivitas. Pembanguan 
tidak seimbang ini oleh Hirschman juga dianggap lebih sesuai untuk dilaksanakan di Negara Sedang Berkembang (NSB), karena negara-negara tersebut menghadapi masalah kekurangan sumber daya.

\section{Produk Domestik Regional Bruto (PDRB)}

Produk Domestik Regional Bruto (PDRB) adalah total nilai produksi barang dan jasa yang diproduksi di suatu wilayah (regional) tertentu dalam waktu tertentu (biasanya satu tahun).

Secara popular, pendekatan penghitungan PDRB dengan metoda 1). pendekatan produksi, 2). pendekatan pengeluaran, dan 3). pendekatan pendapatan.

\section{a. Pendekatan produksi;}

PDRB adalah jumlah nilai barang dan jasa akhir yang dihasilkan oleh berbagai unit produksi di suatu wilayah dalam jangka waktu tertentu (satu tahun). Unit-unit produksi tersebut dalam penyajiannya dikelompokkan menjadi 9 sektor atau lapangan usaha. yaitu: 1. Pertanian; 2. Pertambangan dan Penggalian; 3. Industri Pengolahan; 4. Listrik, Gas. dan Air Bersih; 5. Bangunan; 6. Perdagangan, Hotel dan Restoran; 7. Pengangkutan dan Komunikasi; 8. Keuangan, Persewaan, dan Jasa Perusahaan; 9. Jasa-jasa.

\section{b. Pendekatan pengeluaran;}

PDRB merupakan penjumlahan semua komponen permintaan akhir, yaitu:

1. pengeluaran konsumsi rumah tangga dan lembaga swasta yang tidak mencari untung;

2. konsumsi pemerintah;

3. pembentukan modal tetap domestik bruto;

4. perubahan stok; dan

5. Ekspor netto, dalam jangka waktu tertentu (biasanya satu tahun). Ekspor netto adalah ekspor dikurangi impor.

\section{c. Pendekatan pendapatan ;}

PDRB secara berkala dapat disajikan dalam dua bentuk, yaitu atas dasar harga berlaku dan atas dasar harga konstan pada suatu tahun dasar:

a. Pada penyajian atas dasar harga berlaku ;

Semua agregat pendapatan dinilai atas dasar harga yang berlaku pada masing-masing tahun.

b. Pada penyajian atas dasar harga konstan suatu tahun dasar ;

Semuaagregatpendapatan dinilaiatas dasarharga yang terjadi pada tahun dasar. Karena menggunakan harga konstan (tetap), maka perkembangan agregat dari tahun ke tahun semata-mata disebabkan oleh perkembangan riil dari kuantum produksi tanpa mengandung fluktuasi harga (inflasi/deflasi).

\section{Kriteria Sektor Potensial}

Menurut Kamus Besar Bahasa Indonesia yang dimaksud dengan potensi adalah kemampuan yang mempunyai kemungkinan untuk dikembangkan, kekuatan, kemampuan, kesanggupan, dan daya. Untuk selanjutnya yang dimaksud potential adalah yang mempunyai potensi dan daya kemampuan (Kamus Besar Bahasa Indonesia. 2001; h.890). Jadi yang dimaksud dengan sektor potensial adalah sektor yang mempunyai potensi atau daya kemampuan untuk dikembangkan.

\section{Metode Shift-Share}

Analisis shift-share adalah suatu teknik analisis yang dimaksudkan untuk mengetahui perubahan ekonomi pada suatu daerah terhadap perubahan ekonomi daerah pada tingkat yang lebih tinggi administrasinya. Keterkaitanekonomipadadasarnya menggambarkan hubungan antar perekonomian daerah dengan lingkungan sekitarnya. Bentuk dan sistem keterkaitan tersebut ada dua macam.

a. Hubungan antara daerah atau sektor dengan daerah atau sektor lainnya, ini disebut hubungan shift.

b. Hubungan antar daerah yang lebih rendah administrasinya dengan daerah yang lebih tinggiadministrasinya, ini disebut share.

Dari hasil analisis shift share akan diketahui bagaimana perkembangan suatu sektor disuatu wilayah jika dibandingkan secara relatif dengan sektor-sektor lainya, apakah bertumbuh cepat atau lamban (Budiharsono, 2001)

Pada prinsipnya shift merupakan perubahan tingkat pentingnya suatu sektor tertentu dalam priode waktu tertentu. Sedangkan share menunjukkan peningkatan/ penurunan sektor kegiatan tertentu secara relative kompetitif di suatu wilayah atau terhadap wilayah lain.

Pertumbuhan tenaga kerja/produksi di suatu wilayah antara tahun dasar dengan tahun akhir analisis dibagi menjadi tiga komponen pertumbuhan, yaitu: Komponen pertumbuhan nasiona, komponen pertumbuhan proporsional dan komponen pertumbuhan pangsa wilayah. (Budiharsono, 2001).

Perubahan tenaga kerja/ produksi disuatu wilayah dalam periode waktu tertentu, diakibatkan oleh tiga komponen pertumbuhan yang dapat dijelaskan sebagai berikut :

1. Komponen pertumbuhan Nasional : pertumbuhan kesempatan kerja atau produksi suatu wilayah yang di sebabkan oleh perubahan 
kesempatan kerja atau produksi nasional, perubahan kebijakan ekonomi nasional ataupun perubahan-perubahan situasi yang mempengaruhi perekonomian semua wilayah dan sektor seperti inflasi, defaluasi, perpajakan dan lainnya.

2. Komponen pertumbuhan proprosional atau pertumbuhan industri: perbedaan pertumbuhan dalam sektor karena karena perbedaan permintaan produk akhir, perbedaan ketersediaan bahan mentah, perbedaan dalam kebijakan industri serta perbedaan dalam struktur dan keseragaman pasar.

3. Komponen pertumbuhan pangsa wilayah: perbedaan pertumbuhan yang timbul karena peningkatan/penurunan PDRB atau kesempatan kerja dalam suatu wilayah dengan wilayah yang ditentukan oleh keunggulan komparatif, akses pasar, dukungan kelembagaan, prasarana sosial dan ekonomi serta kebijakan ekonomi regionalpada wilayah tersebut.

Cara menghitung perubahan sektor/ subsektor secara matematis dari ketiga komponen pertumbuhan, yaitu Komponen Pertumbuhan Nasional (PN), Komponen Pertumbuhan Proporsional (PP), dan Komponen Pertumbuhan Pangsa Pasar (PPW) : dapat dinyatakan sebagai berikut (Budiharsono, 2001).

$$
\begin{aligned}
& \Delta Y_{i j}=P N i j+P P i j+P P W i j \\
& \Delta Y_{i j}=Y^{1} i j-Y i j \\
& P N i j=Y i j(R a-1) \\
& P P i j=Y i j(R i-R a) \\
& P P W i j=Y i j(\text { ri-Ri) }
\end{aligned}
$$$$
\text { Atau } \Delta \text { Yij }=\text { PNij }+ \text { PPij }+ \text { PPWij secara }
$$
rinci dapat dinyatakan : (ri-Ri)

$$
\mathrm{Y}^{1} \mathrm{ij}-\mathrm{Yij}=\mathrm{Yij}(\mathrm{Ra}-1)+\mathrm{Yij}(\mathrm{Ri}-1)+\mathrm{Yij}
$$

$$
\begin{aligned}
\mathrm{Ra}=\mathrm{Y}^{1} . . / \mathrm{Y} . & \\
\mathrm{Ri}=\mathrm{Y}^{1} \mathrm{i} / \mathrm{Yi} & \mathrm{Y}_{\mathrm{i}}=\mathrm{Y}^{1} \mathrm{i} / \mathrm{Y}_{\mathrm{ij}} \\
\mathrm{Yi} & =\sum_{j=1}^{m} Y_{i j} \\
Y^{1} i & =\sum_{j=1}^{m} Y^{1}{ }_{i j} \\
Y_{. .} & =\sum_{j=1}^{m} \sum_{j=1}^{m} Y_{i j} \\
Y^{1} . . & =\sum_{j=1}^{m} \sum_{j=1}^{m} Y^{1}{ }_{i j}
\end{aligned}
$$

Keterangan :

$\Delta \mathrm{Yij}=$ Perubahan dalam kesempatan kerja/ produksi sektor i pada wil j.

Yij= Produksi/ tenaga kerja dari sektor i pada wilayah ke j pada tahun dasar analisis.

$\mathrm{Y}^{1} \mathrm{ij} \quad=$ Produktifitas/ tenaga kerja dari sektor $\mathrm{i}$ pada wilayah ke $\mathrm{j}$ pada tahun akhir analisis.

$\mathrm{Yi}=\sum \mathrm{Yij}=$ Produk Domestik Bruto $(\mathrm{PDB})$ atau tenaga kerja (nasional) dari sektor i pada tahun dasar analisis.

$\mathrm{Y}^{1} \mathrm{i} \quad=\sum \mathrm{Y}^{1} \mathrm{ij}=$ Produk Domestik Bruto (PDB) atau tenaga kerja (nasional) dari sektor i pada tahun akhir analisis.

Y.. $=\sum \sum \mathrm{Yij}=$ Produk Domestik Bruto (PDB) atau tenaga kerja (nasional) pada tahun dasar analisis.

$\mathrm{Y}^{1} . . \quad=\sum \sum \mathrm{Y}^{1} \mathrm{ij}=$ Produk Domestik Bruto (PDB) atau tenaga kerja (nasional) pada tahun akhir analisis.

(Ra-1) = Persentase perubahan $\mathrm{PDRB} /$ tenaga kerja yang di sebabkan komponen pertumbuhan nasioanal.

(Ri-1) = Persentase perubahan $\mathrm{PDRB} /$ tenaga kerja yang di sebabkan komponen pertumbuhan proporsional.

$\left(\mathrm{r}_{\mathrm{i}}-\mathrm{R}_{\mathrm{i}}\right) \quad=$ Persentase perubahan $\mathrm{PDRB} /$ tenaga kerja yang di sebabkan komponen pertumbuhan pangsa wilayah.

Apabila PPij < 0, menunjukkan bahwa sektor i pada wilayah ke-j pertumbuhannya lambat. Sedangkan apabila PPij $\geq 0$ menunjukkan bahwa sektor i pada wilayah ke-j pertumbuhannya cepat. Apabila PPWij $\geq 0$, maka berarti bahwa wilayah ke-j mempunyai daya saing yang baik apabila di bandingkan dengan wilayah lainya untuk sektor i. Atau dapat dikatakan bahwa wilayah tersebut mempunyai Comparative advantage untuk sektor i bila di bandingkan dengan wilayah lainnya.

Penjumlahan dua komponen pertumbuhan wilayah, yaitukomponen pertumbuhan proporsional dan komponen pertumbuhan pangsa wilayah dapat digunakan untuk mengidentifikasi pertumbuhan suatu wilayah atau suatu sektor dalam suatu wilayah disebut pergeseran bersih (PB) yang dinyatakan dengan $:$ PBij $=$ PPij + PPW ij

Dimana $\mathrm{PBij}=$ pergeseran bersih sektor $\mathrm{i}$ pada wilayah j.

Apabila $\mathrm{PBij} \geq 0$ maka pertumbuhan sektor $\mathrm{i}$ pada wilayah j termasuk kedalam kelompok progresif (maju). Sedangkan apabila $\mathrm{PBij}<0$, 
maka pertumbuhan sektor i pada wilayah $\mathrm{j}$ termasuk lamban (nonprogresif).

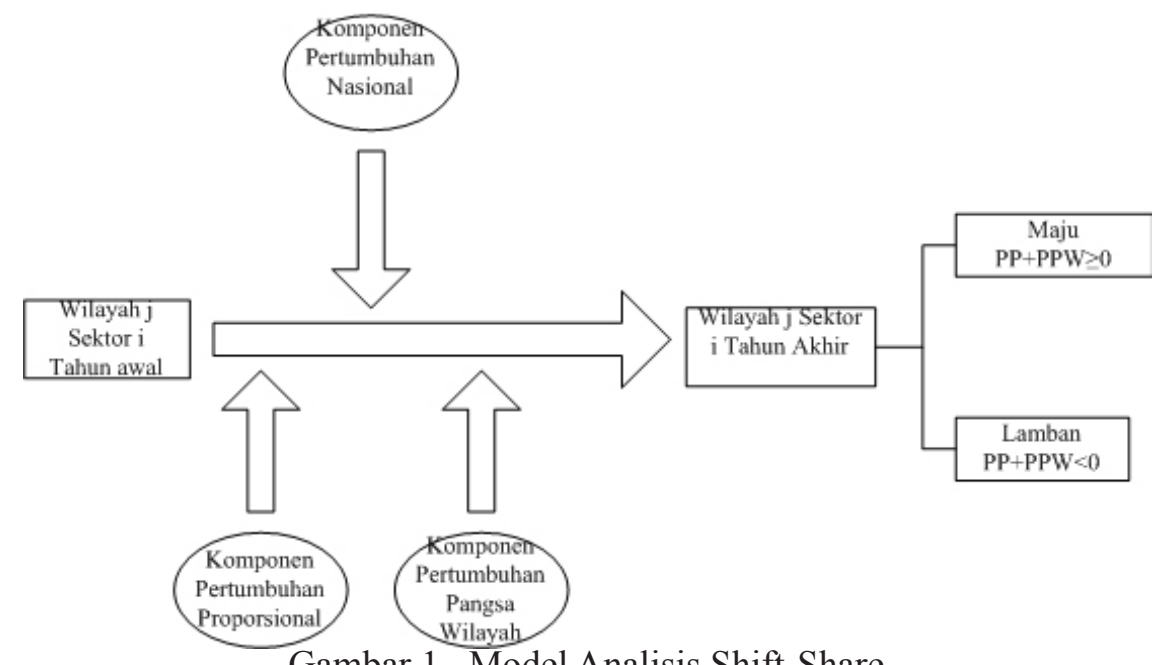

\section{Metode SWOT}

Analisis SWOT adalah Identifikasi berbagai faktor secara sistematis untuk merumuskan strategi. Analisis ini didasarkan pada logika yang dapat memaksimalkan kekuatan (Strength) dan peluang (Opportunities), namun secara bersamaan dapat meminimalkan kelemahan (weaknesses) dan ancaman (Threats), dengan demikian perencanaan strategi (Strtegi plan) harus menganalisis faktorfaktor strategis (kekuatan, kelemahan, peluang dan ancaman) dalam kondisi saat ini disebut analisis situasi. (Rangkuti, 2000).

Analisis SWOT membandingkan antar faktor eksternal : peluang (Opportunities) dan ancaman (Threats) dengan faktor internal : kekuatan (Strenghts) dan kelemahan (Weaknesses). Dari hasil perbandingan tersebut, dapat diperoleh kombinasikombinasi yang akan memunculkan strategi :

1. Kombinasi antara kekuatan (Strenghts) dan
peluang(Opportunities) atau strategi SO menghasilkan strategi agresif, yaitu strategi yang bermanfaat peluang yang terbesar.

2. Kombinasi antara kekuatan (Strenghts) dan ancaman (Threats) atau strategi ST menghasilkan strategi diversifikasi, yaitu strategi yang menggunakan kekuatan untuk mengatasi ancaman.

3. Kombinasi antara kelemahan(Weaknesses) dan peluang(Opportunities) atau strategi WO akan menghasilkan strategi Turn-around, yaitu strategi yang memanfaatkan peluang yang dimiliki untuk mengatasi kelemahan.

4. kombinasi antara kelemahan dan ancaman atau strategi WT menghasilkan strategi defensif, yaitu strategi yang berusaha untuk meminimalkan kelemahan yang ada serta menghindari ancaman. (Rangkuti, 2000).

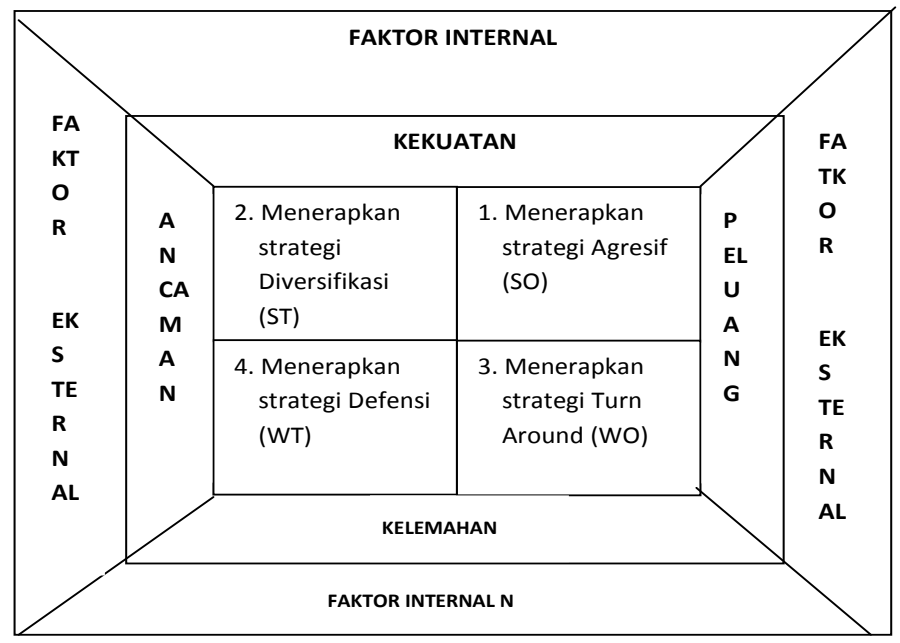

Gambar 2. Diagram Analisis SWOT 


\section{HASIL DAN PEMBAHASAN}

\section{Laju Pertumbuhan}

Dalam penelitian ini, untuk mengukur laju pertumbuhan ekonomi secara total ataupun masing- masing sektor digunakan model yang sederhana, yaitu model rata-rata ukur. Agar dalam analisis lebih tepat maka digunakan Produk Domestik Regional Bruto (PDRB).

Tabel 1. Perkembangan PDRB Kota Gresik dan Propinsi Jawa Timur 2002-2006

\begin{tabular}{|l|r|r|r|r|r|r|}
\hline \multirow{2}{*}{ Sektor } & \multicolumn{3}{c|}{ Kabupaten Gresik } & \multicolumn{3}{c|}{ Propinsi Jawa Timur } \\
& \multicolumn{1}{c|}{$\mathbf{2 0 0 2}$} & \multicolumn{1}{c|}{$\mathbf{2 0 0 6}$} & $\mathbf{r} / \mathbf{t h}(\mathbf{\%})$ & $\mathbf{2 0 0 2}$ & \multicolumn{1}{c|}{$\mathbf{2 0 0 6}$} & \multicolumn{1}{c|}{ r/th(\%) } \\
\cline { 2 - 7 } & $1.154 .378,26$ & $1.210 .226,8$ & 3,85 & 10126,25 & 10986,21 & 2,06 \\
1.PERTANIAN & $205.862,48$ & $210.121,84$ & 6,19 & 1138,20 & 1233,19 & 2,02 \\
2.PERTAMBANGAN DAN PENGGALIAN & $4.607 .683,85$ & $5.675 .608,7$ & 3,38 & 15357,55 & 16420,17 & 1,69 \\
3.INDUSTRI PENGOLAHAN & $405.675,11$ & $553.003,28$ & 6,33 & 1483,16 & 2109,01 & 9,20 \\
4.LISTRIK GAS DAN AIR BERSIH & $540.336,10$ & $668.832,07$ & 4,07 & 2607,91 & 2751,26 & 1,36 \\
5.BANGUNAN KONSTRUKSI & $1.889 .903,94$ & $2.578 .954,8$ & 5,09 & 11908,39 & 16145,59 & 7,91 \\
6.PERDAGANGAN HOTEL \& RESTORAN & $228.516,11$ & $296.554,13$ & 4,15 & 4745,53 & 5888,33 & 5,54 \\
7.PENGANGKUTAN DAN KOMUNIKASI & $369.098,13$ & $433.837,83$ & 4,49 & 3193,52 & 3932,69 & 5,34 \\
8.KEUANGANPERSEWAAN DAN & $198.577,36$ & $242.466,90$ & 3,01 & 6296,01 & 7223,37 & 3,49 \\
JASAPERUSAHAAN & & & & & & \\
9.JASA-JASA & $\mathbf{9 . 6 0 0 . 0 3 1 , 3 4}$ & $\mathbf{1 1 . 8 6 9 . 6 0 6 , 4}$ & $\mathbf{4 , 0 0}$ & $\mathbf{5 6 8 5 6 , 5 2}$ & $\mathbf{6 6 6 8 9 , 8 2}$ & $\mathbf{4 , 0 7}$ \\
\hline
\end{tabular}

Sumber : Diolah dari PDRB Propinsi Jawa Timur dan Kab. Gresik.

Apabila dibandingkan dengan Propinsi Jawa Timur pada periode yang sama, laju pertumbuhan PDRB Kabupaten Gresik masih sedikit dibawahnya. Laju pertumbuhan PDRB Propinsi Jawa Timur rata-rata pertahun meningkat sekitar 4,07 persen, yaitu dari 56.856,52 milyar tahun 2002 menjadi $66.689,82$ milyar pada tahun 2006. Namun dernikian ada 4 (empat) sektor yang laju pertumbuhannya di atas Propinsi jawa Timur, yaitu sektor pertanian, sektor pertambangan dan penggalian, sektor indutri pengolahan serta sektor bangunan/konstruksi.

\section{Struktur Ekonomi Daerah}

Peran sektor pertanian dalam struktur ekonomi 2002-2006 sedikit mengalami penurunan. Pada 2002 peranan sektor pertanian masih sebesar $\quad 12 \%$ dan tahun 2006 turun menjadi 10,19\%. Perubahan ini bukan berarti sektor pertanian mengalami penurunan tetapi karena sektor lain tumbuh lebih cepat.

Tabel 2. PDRB Kabupaten Gresik dan Konstribusi Sektor Tahun 2002-2006

\begin{tabular}{|c|c|c|c|c|c|}
\hline \multirow{2}{*}{\multicolumn{2}{|c|}{ Sektor }} & \multicolumn{2}{|l|}{ Tahun 2002} & \multicolumn{2}{|l|}{ Tahun 2006} \\
\hline & & $\begin{array}{l}\text { Jumlah (juta } \\
\text { rupiah) }\end{array}$ & $\%$ & $\begin{array}{l}\text { Jumlah (juta } \\
\text { rupiah) }\end{array}$ & $\%$ \\
\hline (1) & & (2) & $(3)$ & & $(5)$ \\
\hline 1. & Pertanian & $1.154 .378,26$ & 12,027 & $1.210 .226,89$ & 10,196 \\
\hline 2. & $\begin{array}{l}\text { Pertambangan dan } \\
\text { penggalian }\end{array}$ & $205.862,48$ & 2,144 & $210.121,84$ & 1,77 \\
\hline 3. & Industri pengolahan & $4.607 .683,85$ & 47,996 & $5.675 .608,70$ & 47,816 \\
\hline 4. & $\begin{array}{l}\text { Listrik, gas dan air } \\
\text { bersih }\end{array}$ & $405.675,11$ & 4,227 & $553.003,28$ & 4,659 \\
\hline 5. & Bangunan /konstruksi & $540.336,10$ & 5.628 & $668.832,07$ & 5,635 \\
\hline 6. & $\begin{array}{l}\text { Perdagangan, hotel } \\
\text { dan restoran }\end{array}$ & $1.889 .903,94$ & 19,868 & $2.578 .954,80$ & 21,727 \\
\hline 7. & $\begin{array}{l}\text { Pengangkutan dan } \\
\text { komunikasi }\end{array}$ & $228.516,11$ & 2,38 & $296.554,13$ & 2,498 \\
\hline & $\begin{array}{l}\text { Keuangan, persewaan } \\
\text { dan jasa perusahaan }\end{array}$ & $369.098,13$ & 3,844 & $433.837,83$ & 3,655 \\
\hline$\frac{9}{J u r}$ & $\frac{\text { Jasa-jasa }}{\text { ah }}$ & $\frac{198,577,36}{9.600 .031,34}$ & $\frac{2.068}{100,00}$ & $\frac{242.466,90}{11.869 .606,44}$ & $\frac{2,043}{100,00}$ \\
\hline
\end{tabular}


Demikian juga yang terjadi pada sektor industri pengolahan, dimana nilainya mengalami peningkatan dari Rp. 4.607.683,85 (pada tahun 2002) menjadi Rp. 5.675.608,70 (tahun 2006). Sedangkan kontribusinya mengalami penurunan dari 47,99\% (pada tahun 2002) menjadi 47,81\% (tahun 2006).

Sektor perdagangan, hotel dan restoran merupakan sektor ketiga terbesar kontribusinya pada pembentukan PDRB setelah sektor industri pengolahan dan sektor pertanian. Peningkatan nilai tambah bruto (NTB) pada sektor ini juga diikuti dengan dengan konstribusi yang lain.

Perkembangan ekonomi di kabupaten Gresik dari tahun ke tahun menunjukkan arah yang posistif hal ini ditinjau dari struktur ekonomi yang ada, pilar utamanya adalah sektor industri pengolahan.

Terhadap sumbangannya pada PDRB ada beberapa sektor diantaranya :

1. Sektor Industri pengolahan menyumbang 48,63 $\%$ dari seluruh konstruksi ekonomi daerah Gresik.

2. Sektor Perdagangan, Hotel dan Restoran dengan sumbangan 22,98\%.

3. Sektor Pertanian dengan sumbangan $9,38 \%$.

4. Sektor bangunan/ konstruksi 5,5\%.

5. Sektor listrik, gas dan air bersih sebesar $4,44 \%$.

6. Sektor Keuangan, persewaan dan jasa perusahaan sebesar $3,82 \%$.

7. Sektor transportasi dan komunikasi sebesar $2,23 \%$.

8. Sektor Jasa sebesar 1,72\%.

9. Sektor Pertambangan dan Galian sebesar $1,13 \%$.

\section{Perkembangan Ekonomi Sektoral}

Tabel 3. Perkembangan sektor-sektor ekonomi Gresik tahun 2002-2006

\begin{tabular}{|c|c|c|c|c|c|}
\hline & \multirow[b]{2}{*}{ Lapangan usaha } & \multicolumn{2}{|c|}{ PDRB (jutaan rupiah) } & \multirow{2}{*}{$\begin{array}{l}\text { Perubahan } \\
\text { PDRB }\end{array}$} & \multirow{2}{*}{$\begin{array}{l}\text { Persentase } \\
\text { perubahan }\end{array}$} \\
\hline & & Tahun 2002 & Tahun 2006 & & \\
\hline 1 & $\begin{array}{r}(1) \\
\text { Pertanian }\end{array}$ & 115437826 & $(3)$ & (4) & \\
\hline 1. & Pertanian & 1.154.378,26 & $1.210 .226,89$ & 55848,63 & 4,83 \\
\hline 2. & $\begin{array}{l}\text { Pertambangan dan } \\
\text { penggalian }\end{array}$ & $205.862,48$ & $210.121,84$ & $4.259,36$ & 2,07 \\
\hline 3. & Industri pengolahan & $4.607 .683,85$ & $5.675 .608,70$ & $1.067 .924,85$ & 23,18 \\
\hline 4. & $\begin{array}{l}\text { Listrik, gas dan air } \\
\text { bersih }\end{array}$ & $405.675,11$ & $553.003,28$ & $147.328,17$ & 36,32 \\
\hline 5. & $\begin{array}{l}\text { Bangunan / } \\
\text { konstruksi }\end{array}$ & $540.336,10$ & $668.832,07$ & $128.495,97$ & 23,78 \\
\hline 6. & $\begin{array}{l}\text { Perdagangan, hotel } \\
\text { dan restoran }\end{array}$ & $1.889 .903,94$ & $2.578 .954,80$ & $689.050,86$ & 36,46 \\
\hline 7. & $\begin{array}{l}\text { Pengangkutan dan } \\
\text { komunikasi }\end{array}$ & $228.516,11$ & $296.554,13$ & $68.038,02$ & 29,77 \\
\hline 8. & $\begin{array}{l}\text { Keuangan, } \\
\text { persewaan dan jasa } \\
\text { perusahaan }\end{array}$ & $369.098,13$ & $433.837,83$ & $64.739,7$ & 17,54 \\
\hline & $\begin{array}{c}\text { Jasa-jasa } \\
\text { PDRB }\end{array}$ & $\begin{array}{r}198.577,36 \\
9.600 .031,34\end{array}$ & $\begin{array}{r}242.466,90 \\
11.869 .606,44\end{array}$ & $\begin{array}{r}43.889 .54 \\
2.269 .575,1\end{array}$ & $\begin{array}{l}22,10 \\
23,64\end{array}$ \\
\hline
\end{tabular}

Sumber : Diolah dari BPS Kabupaten Gresik.

Contoh Perhitungan dalam menentukan perubahan PDRB

Perubahan PDRB Pertn $=\sum$ PDRB th $2006-\Sigma$ PDRB th 2002

$1.154 .378,26$

$$
=1.210 .226,89 \text { - }
$$

$$
=55848,63
$$

Perubahan PDRB Pertb $=210.121,84$ $205.862,48$

$$
=4.259,36
$$

\section{Hasil Shift-Share Untuk Sektor Berpotensi}

$\mathrm{Ra}=\mathrm{Y}^{1} . . / \mathrm{Y} .$.
$=$ Jumlah PDB (produk domestik bruto) pada tahun akhir analisis

Jumlah PDB (produk domestik bruto) pada tahun dasar analisis

$$
\begin{array}{rlr}
= & 11.869 .606,4 & \\
& 9.600 .031,34 & \\
= & 1,236 & \\
\mathrm{Ri}= & \mathrm{Y}^{1} \mathrm{i} / \mathrm{Yi} & \mathrm{ri}=\mathrm{Y}^{1} \mathrm{i} / \mathrm{Y}_{\mathrm{ij}} \\
= & 10.986,21 & \mathrm{ri}=1.210 .226,89 \\
& 10.126,25 & 1.154 .378,26 \\
= & 1,085 & =1,048
\end{array}
$$


Tabel 4. Nilai Ra, Ri dan ri Hasil Perhitungan Analisis Shift-Share

\begin{tabular}{|c|c|c|c|c|c|c|c|c|}
\hline & & Lapangan usaha & Ra & Ri & ri & $($ Ra-1) & (Ri-Ra) & (ri-Ri) \\
\hline 1 & & PERTANIAN & $\frac{(2)}{1,236}$ & $\frac{(3)}{1,085}$ & 1,048 & $\frac{(5)}{0,236}$ & $\frac{(6)}{-0,151}$ & $\begin{array}{l}(7) \\
-0,037\end{array}$ \\
\hline & 1.1 & Tanaman bahan makanan & 1,236 & 1,054 & 0,978 & 0,236 & $-0,182$ & $-0,078$ \\
\hline & 1.2 & Tanaman perkebunan & 1,236 & 1,108 & 1,067 & 0,236 & $-0,128$ & $-0,041$ \\
\hline & 1.3 & Peternakan dan hasil-hasilnya. & 1,236 & 1,155 & 1,088 & 0,236 & $-0,008$ & $-0,067$ \\
\hline & 1.4 & Kehutanan & 1,236 & 0,678 & - & 0,236 & $-0,558$ & - \\
\hline & 1.5 & Perikanan & 1,236 & 1,355 & 1,119 & 0,236 & 0,119 & $-0,236$ \\
\hline 2 & & PERTAMBANGAN \& GALIAN & 1,236 & 1,083 & 1,020 & 0,236 & $-0,153$ & $-0,063$ \\
\hline & 2.1 & Pertambangan migas & 1,236 & 0,397 & - & 0,236 & $-0,839$ & - \\
\hline & 2.2 & Pertambangan non migas & 1,236 & 1,336 & - & 0,236 & 0,1 & - \\
\hline & 2.3 & Penggalian & 1,236 & 1,198 & 1,020 & 0,236 & $-0,038$ & $-0,178$ \\
\hline 3 & & INDUSTRI PENGOLAHAN & 1,236 & 1,069 & 1,231 & 0,236 & $-0,167$ & 0,162 \\
\hline & 3.1 & $\begin{array}{l}\text { Industri makanan, minuman } \\
\text { dan tembakau }\end{array}$ & 1,236 & 0,979 & 1,102 & 0,236 & $-0,257$ & 0,203 \\
\hline & 3.2 & $\begin{array}{l}\text { Industri tekstil, pakaian jadi dan } \\
\text { kulit }\end{array}$ & 1,236 & 0,981 & 1,255 & 0,236 & $-0,259$ & 0,274 \\
\hline & 3.3 & $\begin{array}{l}\text { Industri kayu, banbu, rotan } \\
\text { perabotan RT }\end{array}$ & 1,236 & 1,088 & 1,164 & 0,236 & $-0,148$ & 0,076 \\
\hline & 3.4 & $\begin{array}{l}\text { Industri kertas, percetakan dan } \\
\text { penerbitan }\end{array}$ & 1,236 & 1,379 & 1,288 & 0,236 & 0,143 & $-0,091$ \\
\hline & 3.5 & $\begin{array}{l}\text { Industri pupuk, kimia, barang } \\
\text { dari karet dan plastic }\end{array}$ & 1,236 & 1,245 & 1,180 & 0,236 & 0,009 & $-0,065$ \\
\hline & 3.6 & $\begin{array}{l}\text { Industri semen dan barang } \\
\text { galian bukan logam }\end{array}$ & 1,236 & 1,252 & 1,237 & 0,236 & 0,016 & $-0,015$ \\
\hline & 3.7 & Industri logam dasar & 1,236 & 1,242 & 1,337 & 0,236 & 0,006 & 0,095 \\
\hline & 3.8 & $\begin{array}{l}\text { Industri barang dari logam, } \\
\text { mesin danperalatannya }\end{array}$ & 1,236 & 1,092 & 1,356 & 0,236 & $-0,144$ & 0,264 \\
\hline & 3.9 & Industri pengolahan lainnya & 1,236 & 1,165 & 1,330 & 0,236 & $-0,071$ & 0,165 \\
\hline 4 & & LISTRIK, GAS \& AIR BERSIH & 1,236 & 1,422 & 1,363 & 0,236 & 0,186 & $-0,059$ \\
\hline & 4.1 & & 1,236 & 1,412 & 1,363 & 0,236 & 0,176 & $-0,049$ \\
\hline & 4.2 & & 1,236 & 2,015 & - & 0,236 & 0,779 & - \\
\hline & 4.3 & Air bersih & 1,236 & 1,124 & 1,299 & 0,236 & $-0,112$ & 0,175 \\
\hline 5 & & BANGUNAN KONSTRUKSI & 1,236 & 1,055 & 1,237 & 0,236 & $-0,181$ & 0,182 \\
\hline 6 & & $\begin{array}{l}\text { PERDAGANGAN, HOTEL DAN } \\
\text { RESTORAN }\end{array}$ & 1,236 & 1,356 & 1,364 & 0,236 & 0,121 & 0,008 \\
\hline & 6.1 & Perdagangan besar dan eceran & 1,236 & 1,337 & 1,373 & 0,236 & 0,101 & 0,036 \\
\hline & 6.2 & Hotel & 1,236 & 1,191 & 1,621 & 0,236 & $-0,045$ & 0,43 \\
\hline & 6.3 & Restoran & 1,236 & 1,491 & 1,275 & 0,236 & 0,255 & $-0,216$ \\
\hline 7 & & PENGANKUTAN DAN & 1,236 & 1,241 & 1,297 & 0,236 & 0,005 & 0,056 \\
\hline & 7.1 & NUIVIUIVINASI & 1,236 & 1,140 & 1,261 & 0,236 & $-0,096$ & 0,121 \\
\hline & & AIVGNUTAIN & 1,236 & 0,715 & 1,358 & 0,236 & $-0,521$ & 0,643 \\
\hline & & IEI & 1,236 & 1,043 & 1,261 & 0,236 & 0,193 & 0.218 \\
\hline
\end{tabular}

Sumber : Diolah dari PDRB Propinsi Jawa Timur dan Kabupaten Gresik 


\section{Pembahasan}

\section{A. Sektor industri pengolahan}

Terhadap sumbangannya pada PDRB, sektor industri pengolahan pada urutan pertama menyumbang konstribusi sebesar 47,816 persen dengan nilai PDRB Rp. 5.675.608.70.000,- dari seluruh konstruksi ekonomi daerah Gresik. Dengan banyaknya industri, akan ada kecendrungan semakin cepat berdiri industri baru yang merupakan mata rantai industri yang saling menunjang.

Apabila diamati berdasarkan sub sektornya, maka sub sektor terbesar terdapat pada kelompok makanan, minuman dan tembakau. Sub sektor ini mempunyai kontribusi yang paling tinggi terhadap pembentukan PDRB, yaitu rata-rata 19,43\%. Dengan laju pertumbuhan yang cukup tinggi sebesar 4,62 \% per tahun diharapkan sub sektor makanan, minuman dan tembakau ini mampu menjadi penunjang utama dari sektor industri pengolahan, sehingga pada akhirnya dapat meningkatkan perekonomian di kabupaten Gresik.

Sub sektor semen dan barang galian bukan logam mempunyai laju pertumbuhan yang lebih tinggi dari sub sektor makanan, minuman dan tembakau ( 5,91 persen per tahun ) namun kontribusinya agak kecil pada pembentukan PDRB yaitu rata-rata hanya 1,15 persen. Untuk itu sub sektor ini pada masa mendatang diharapkan mampu memberikan kontribusi yang lebih besar bagi peningkatan sektor industri pengolahan.

\section{B. Sektor perdagangan, hotel dan Restoran}

Sektor perdagangan, hotel dan restoran merupakan sektor ekonomi kedua yang juga mempunyaikontribusiyangbesarbagiperekonomian setelah sektor industri pengolahan. Selama tahun 2006 kontribusi sektor ini sebesar 21,727 \% dengan PDRB mencapai Rp. 2.578.954.800.000,-Penyumbang sektor ini diperoleh dari sub sektor perdagangan besar dan eceran dengan kontribusi rata-rata sebesar 15,75 persen dari laju pertumbuhan ekonomi 4,73 persen per tahun.

\section{Sektor Pertanian}

Sektor pertanian adalah sektor ekonomi yang memberikan kontribusi terbesar ketiga setelah sektor industri pengolahan dan perdagangan, hotel dan Restoran pada pembentukan PDRB kabupaten Gresik tahun 2006, yaitu 10,196 persen dengan PDRB sebesar Rp. 1.210.226.890.000,-. Kontribusi pada sektor ini diberikan oleh subsektor tanaman bahan makanan sebesar 13,57\%.

Sub sektor perkebunan dalam pembentukan 108
PDRB kabupaten Gresik kontribusinya hanya 3,79 $\%$ laju pertumbuhan rata-rata 2,67\% pertahunnya.

Peranan Sub sektor perikanan pada pembentukan PDRB sangat kecil hanya 0,03\%, Namun laju pertumbuhan sub sektor ini dari tahun 2002-2006 cukup tinggi yaitu rata-ratr 15,91\% per tahunnya.

\section{Analisis SWOT}

Sektor Industri Pengolahan dan Sektor perdagangan, hotel dan restoran :

1. Faktor Internal :

- Kekuatan (Strenght) : 1). Tersedianya sarana dan prasarana pendukung usaha industri pengolahan yang memadai, 2). Tersedianya kawasan khusus untuk industri.

- Kelemahan (Weakness) : 1). Tcrbatasnya SDM (buruh/pekerja) yang berkualitas, 2). Masih lemahnya manajemen pengelolaan industri pengolahan.

2. Faktor Eksternal

- Peluang (Opportunity) : 1). Tersedianya sumber daya alam yang mendukung industri pengolahan, 2). Letak geografis yang strategis sebagai lalu lintas jalur perdagangan antar kabupaten/kota

- Ancaman (Treath) : 1). Menurunnya tingkat kesejahteraan tenaga kerja, 2). Terdapat ketimpangan distribusi pendapatan tenaga kerja

\section{Sektor Pertanian :}

1. Faktor Internal :

- Kekuatan (Strenght) : 1). Tersedianya sarana dan prasarana pendukung usaha pertanian yang memadai, 2). Masih luasnya lahan sawah yang digunakan untuk pertanian tanaman pangan.

- Kelemahan (Weakness) : 1). Rendahnya kualitas hasil produksi pertanian, 2). Masih lemahnya manajemen pemasaran hasil produksi pertanian.

2. Faktor Eksternal

- Peluang (Opportunity) : 1). Adanya potensi unggulan di bidang pertanian dan agrobisnis yang dapat dikembangkan dan mempunyai nilai investasi tinggi, 2). Letak geografis yang strategis dalam jalur lalu lintas perdagangan antar kabupaten/kota

- Ancaman (Treath) : 1). Menurunnya tingkat kesejahtraan petani, ketimpangan

2). Terdapat masyarakat.

distribusi pendapatan




\section{E. Rancangan Strategi Pengembangan Sektor Ekonomi Potensial \\ Sektor pertanian (sub sektor tanaman bahan makanan) :}

- Strategi S-O,

1. Meningkatkan penyediaan sarana dan prasarana transportasi sebagai penunjang pemasaran hasil-hasil produksi pertanian.

2. Meningkatkan peranan koperasi dalam penyediaan sarana dan prasarana produksi, permodalan maupun dalam pemasaran hasilhasil pemasaran hasil-hasil pertaniannya.

3. Meningkatkan produktifitas lahan pertanian guna menaikkan tingkat kesejahteraan petani. Meningktkan efisiensi dan produktifitas pembangunan pertanian, yang di upayakan melalui konsolidasi luasan usaha tani dan ketepatan penyediaan sarana produksi pertanian.

4. Meningkatkan system pengendalian dan penenggulangan hama terpadu di bidang pertanian tanaman pangan.

- Strategi W-O

1. Meningkatkan kualitas hasil-hasil produk unggulan pertanian dan agrobisnis agar mempunyai daya saing tinggi. Untuk itu perlu memperkuat system penyuluhan dan pembinaan terhadap petani.

2. Pengembangan sentra-sentra perdagangan produk-produk unggulan pertanian dan agrobisnis di tempat-tempat strategis.

3. Pengembangan kerja sama dengan kabupaten/ kota terdekat guna meningkatkan pemasaran hasil-hasil pertanian.

4. Peningkatkan system pemasaran hasil-hasil produk pertanian dengan memanfaatkan lokasi strategis lintas jalur perdagangan sebagai jalur perdagangan sebagai lahan promosi yang efektif.

\section{- Strategi W-T}

1. Melakukan diversifikasi hasil produksi pertanian sesuai dengan permintaan dan kebutuhan pasar. Kegiatan ini harus juga di barengi dengan pencarian pangsa pasar baru bagi bentuk produk hasil diversifikasi.

2. Memberikan kemudahan petani untuk memperoleh pinjaman kredit lunak agar dapat menjalankan usaha pertaniannya.

3. Mempertahankan kelompok-kelompok petani yang sudah ada untuk saling bekerja sama mengatasi hambatan-hambatan dalam mengembangkan usaha di bidang pertanian terutama dalam memasarkan produk hasil pertanian.

4. Mempertahankan system manajemen pemasaran yang sudah ada agar ketimpangan distribusi pendapatan petani tidak menjadi semakin melebar.

\section{Sektor Industri Pengolahan dan Sektor} perdagangan, hotel dan restoran

- Strategi S-O

1. Meningkatkan penyediaan sarana dan prasarana akomodasi maupun transportasi.

2. Mengembangkan sentra-sentra perdagangan hasil-hasil industri pengolahan.

3. Membentuk kawasan industri terpadu melalui pengembangan klaster industri. Dengan terbentuknya klaster industri dapat mendorong tumbuhnya jaringan industri yang memerlukan suplai bahan baku dan penolong yang sama sehingga memperkuat partnership antara industri inti, terkait dan pendukung.

4. Meningkatkan system promosi dan birokasi bagi pengembangan investasi di daerah kawasan industri dengan memanfaatkan tempat-tempat strategis pada jalur lalulintas perdagangan.

- $\quad$ Strategi S-T

1. Penyediaan sarana dan prasarana transportasi yang murah dan memadai untuk mengangkut bahan baku maupun hasil-hasil industri, sehingga biaya produksi dapat di tekan oleh perusahaan. Rendahnya biaya produksi diharapkan dapat meningkatkan upah yang di terima buruh / pekerja untuk memperbaiki tingkat kesejahtraanya.

2. Meningkatkan peran koperasi usaha mikro kecil dan menengah (dalam menunjang pengembangan sektor industri.

3. Menyediakan tempat tinggal murah bagi buruh/ pekerja di sekitar kawasan industri.

4. Menciptakan iklim usaha yang lebih kondusif bagi industri yang sudah ada maupun investasi baru dalam bentuk tersedianya layanan yang baik dan bersih dari KKN, sumber-sumber pendanaan yang terjangkau dan kebijaksanaan fiscal yang menunjang sehingga mampu menumbuhkan industri potensial. 
- Strategi W-O

1. Meningkatkan kemampuan dan ketrampilan buruh/ pekerja dalam penguasaan teknologi modern guna peningkatan poduktifitasnya.

2. Peningkatan kualitas SDM dalam bidang manajeman pengelolaan industri akan menghasilkan produk-produkyang bersih dari pencemaran lingkungan.

3. Mengembangkan system pengelolaan sumber daya alam guna menunjang industri pengolahan.

4. Pengembangan kerja sama dengan kabupaten/ kota terdekat guna peningkatan system pengelolaan dan pemasaran hasil-hasil industri pengolahan. Kerja sama tersebut lebih di tekankan pada pemenuhan produk-produk industri sesuai kebutuhan pasar di daerah masing-masing daerah dapat memperoleh keuntungan dengan memanfaatkan pangsa pasar yang ada untuk memasarkan hasil-hasil industrinya.

- Strategi W-T

1. Memberikan jaminan ekonomi dan sosial bagi buruh/ pekerja agar produktifitasnya tidak terganggu.

2. Memberikan pembinaan serta menyalurkan buruh/ pekerja sesuai dengan kemampuan dan skill yang dimiliki.

3. Mempertahankan system manajemen pengupahan yang sudah ada agar ketimpangan distribusi pendapatan buruh/ pekerja tidak smakin melebar.

\section{KESIMPULAN}

1. Hasil analisis shift-share dan pengamatan terhadap data empiris di wilayah kabupaten Gresik menghasilkan tiga sektor potensial yaitu sektor industri pengolahan, sektor perdagangan, hotel dan restoran serta sektor pertanian.

2. Rancangan strategi pengembangan sektor pertanian
a. Meningkatkan penyediaan sarana dan prasarana transportasi.
b. Meningkatkan peranan koperasi dalam penyediaan sarana dan prasarana produksi, permodalan maupun dalam pemasaran.
c. Meningkatkan produktifitas lahan pertanian.
d. Meningkatkan system pengendalian dan penenggulangan hama terpadu.
e. Meningkatkan kualitas hasil-hasil produk

unggulan.

f. Pengembangan sentra-sentra perdagangan produk-produk unggulan di tempat-tempat strategis.

g. Pengembangan kerja sama dengan kabupaten/ kota terdekat.

h. Melakukan diversifikasi hasil produksi pertanian sesuai dengan permintaan dan kebutuhan pasar.

i. Memberikan kemudahan petani untuk memperoleh pinjaman kredit lunak.

j. Mempertahankan kelompok-kelompok petani yang sudah ada untuk saling bekerja sama.

3. Rancangan strategi pengembangan sektor Industri Pengolahan dan Sektor perdagangan, hotel dan restoran

a. Meningkatkan penyediaan sarana dan prasarana akomodasi maupun transportasi yang terjangkau harganya dan memadai.

b. Mengembangkan sentra-sentra perdagangan.

c. Membentuk kawasan industri terpadu melalui pengembangan klaster industri..

d. Meningkatkan system promosi dan birokasi bagi pengembangan investasi di daerah kawasan industri dengan memanfaatkan tempat-tempat strategis pada jalur lalulintas perdagangan.

e. Meningkatkan peran koperasi usaha mikro kecil dan menengah dalam menunjang pengembangan sektor industri.

f. Menyediakan tempat tinggal murah bagi tenaga kerja di sekitar kawasan industri.

g. Menciptakan iklim usaha yang lebih kondusif.

h. Meningkatkankemampuandanketrampilan tenaga kerja dalam penguasaan teknologi modern.

i. Peningkatan kualitas SDM dalam bidang manajeman pengelolaan industri akan menghasilkan produk-produk yang ramah lingkungan.

j. Pengembangan kerja sama dengan kabupaten/ kota terdekat guna peningkatan system pengelolaan dan pemasaran hasilhasil industri pengolahan.

k. Memberikan jaminan ekonomi dan sosial bagi tenaga kerja agar produktifitasnya tidak terganggu.

1. Memberikan pembinaan serta menyalurkan 
tenaga kerja sesuai dengan kemampuan dan skill yang dimiliki.

m. Mempertahankan system manajemen pengupahan yang baik.

\section{DAFTAR PUSTAKA}

Arsyad, Lincolin. (1990) Pengantar Perencanaan Dan Pembangunan Ekonomi Daerah, Edisi pertama, BPFE, Yogyakarta.

Boediono, (1999) Teori Pertumbuhan Ekonomi, Edisi Pertama, BPFE, Yogyakarta.

Boediharsono, S. (2001) Teknik Analisis Pembangunan Wilayah Pesisir dan Lautan, Edisi Pertama, PT Pradya Paramita, Jakarta.

Budi Santoso, Agus. (2003) Strategi Peningkatan Perekonomian Daerah Melalui Pengembangan Sector Ekonomi Potensial (Studi Kasus Di Kabupaten Mojokerto), skripsi, Institut Teknologi Sepuluh Nopember, Surabaya.

BPS dan BAPPEKAB Gresik (2006) Kabupaten Gresik Dalam Angka 2000-2006, kerjasama BAPPEKAB dan BPS Kabupaten Gresik.

BPS dan BAPPEKAB kabupaten Gresik (2006) Pendapatan Regional Kabupaten Gresik 2000-2006, kerjasama BAPPEKAB dan BPS Kabupaten Gresik.

Herzog H.W and Olsen, R (1977) Shift-share Analysis Revisited: The Allocation Effect and Stability of Regional Structure, OAK Ridge Natonal Laboratory, Tenesse.

Hunger, J. David \& Thomas I, Wheelen, (2003) Manajemen Strategis, Edisi Kedua, Andi, Yogyakarta.

Nasir, Moh. (1983) Metode Penelitian, Edisi keempat, Ghalia Indonesia, Jakarta.

Priadi, Agung (2005) Analisis Strutuktur Ekonomi Atas Dasar Tenaga Kerja Propinsi Jawa Timur, skripsi, Program Studi Ekonomi Pembangunan Fak. Ekonomi, Univ. Islam Indonesia, Jogjakarta.

Rangkuti, Freddy (2001) Analisis SWOT Teknik Membedah Kasus Bisnis, Edisi Ketujuh, PT. Gramedia Pustaka Utama, Jakarta.

Saerofi, Mujib. (2005) Analisis Pertumbuhan Ekonomi dan Pengembangan Sektor Potensial di Kabupaten Semarang, skripsi, Jurusan Ekonomi, Fak. Ilmu Sosial, Univ. Negeri Semarang, Semarang.

Tjokroamiddjojo, B. (1996), Perencanaan Pembangunan, Edisi Ke-19, PT. Gunung
Agung, Jakarta.

Todaro, Michael P. (2000), Ekonomi Pembangunan, Erlangga, Jakarta. 